\title{
Effect of Temperature on the Corrosion Inhibition of Trans-4-Hydroxy-4' -Stilbazole on Mild Steel in HCl Solution
}

\author{
Ayssar Nahlé, Ideisan I. Abu-Abdoun, and Ibrahim Abdel-Rahman \\ Department of Chemistry, College of Sciences, University of Sharjah, P.O. Box 27272, Sharjah, United Arab Emirates \\ Correspondence should be addressed to Ayssar Nahlé, anahle@sharjah.ac.ae
}

Received 21 January 2012; Accepted 16 March 2012

Academic Editor: Vesna Mišković-Stanković

Copyright () 2012 Ayssar Nahlé et al. This is an open access article distributed under the Creative Commons Attribution License, which permits unrestricted use, distribution, and reproduction in any medium, provided the original work is properly cited.

The inhibition and the effect of temperature and concentration of trans-4-hydroxy-4'-stilbazole on the corrosion of mild steel in $1 \mathrm{M} \mathrm{HCl}$ solution was investigated by weight loss experiments at temperatures ranging from 303 to $343 \mathrm{~K}$. The studied inhibitor concentrations were between $1 \times 10^{-7} \mathrm{M}$ and $1 \times 10^{-3} \mathrm{M}$. The percentage inhibition increased with the increase of the concentration of the inhibitor. The percentage inhibition reached about $94 \%$ at the concentration of $1 \times 10^{-3} \mathrm{M}$ and $303 \mathrm{~K}$. On the other hand, the percentage inhibition decreased with the increase of temperature. Using the Temkin adsorption isotherm, the thermodynamic parameters for the adsorption of this inhibitor on the metal surface were calculated. Trans-4-hydroxy-4' -stilbazole was found to be a potential corrosion inhibitor since it contained not only nitrogen and oxygen, but also phenyl and pyridine rings that are joined together with a double bond $(-\mathrm{C}=\mathrm{C}-)$ in conjugation with these rings.

\section{Introduction}

Organic compounds containing polar groups by which the molecule can become strongly or specifically adsorbed on the metal surface constitute most organic inhibitors $[1,2]$. These inhibitors, which include the organic $\mathrm{N}, \mathrm{P}, \mathrm{S}$, and $\mathrm{OH}$ groups, are known to be similar to catalytic poisons, as they decrease the reaction rate at the metal/solution interface without, in general, being involved in the reaction considered. It is generally accepted that most organic inhibitors act via adsorption at the metal/solution interface. The mechanism by which an inhibitor decreases the corrosion current is achieved by interfering with some of the steps for the electrochemical process.

The corrosion inhibition of mild steel in aggressive acidic solutions has been widely investigated. In industries, hydrochloric acid solutions are often used in order to remove scale and salts from steel surfaces, and cleaning tanks and pipelines. This treatment may be prerequisite for coating by electroplating, galvanizing, or painting techniques. The acid must be treated to prevent an extensive dissolution of the underlying metal. This treatment involves the addition of some organic inhibitors to the acid solution that adsorb at the metal/solution interface by displacing water molecules on the surface and forming a compact barrier film.

Many authors have used various nitrogen-containing compounds in their corrosion inhibition investigations. These compounds included quaternary ammonium salts [310], polyamino-benzoquinone polymers [11], azoles [1219], substituted aniline-N-salicylidenes [20], amides [21], heterocyclic compounds [22, 23], and cationic surfactants [24, 25]. Other authors worked on sulfur-containing inhibitors [26-31]. Other studies involved the effect of addition of some ions on the inhibition efficiency of some organic compounds. These ions included chromium [32], iodide $[33,34]$, and chloride $[35,36]$. Structural effect of organic compounds as corrosion inhibitors was also studied $[17,34,37-39]$. In all these studies, the nitrogen atom(s) in the compounds showed to be able to absorb very well on the metal surface and form protective layer, which in turn increased the corrosion inhibition with the increase in the concentration of the inhibitor, in some cases reaching $99 \%$ inhibition $[5,40,41]$.

No studies have been reported on trans-4-hydroxy-4' stilbazole inhibitor employed in this current work, in terms of studying the effect of temperature on the corrosion 
TABLE 1: Effect of concentration of trans-4-hydroxy-4 $4^{\prime}$-stilbazole on the corrosion rate $\left(\mathrm{mg} \cdot \mathrm{cm}^{-2} \cdot \mathrm{h}^{-1}\right)$ and percentage efficiency of mild steel in $1 \mathrm{M} \mathrm{HCl}$ at various temperatures.

\begin{tabular}{|c|c|c|c|c|c|c|c|c|c|c|}
\hline \multirow[b]{3}{*}{$\begin{array}{l}\text { Concentration of } \\
\text { inhibitor }\end{array}$} & \multicolumn{10}{|c|}{ Temperature/k } \\
\hline & \multicolumn{2}{|c|}{303} & \multicolumn{2}{|c|}{313} & \multicolumn{2}{|c|}{323} & \multicolumn{2}{|c|}{333} & \multicolumn{2}{|c|}{343} \\
\hline & $\begin{array}{l}\text { Corr. } \\
\text { Rate }\end{array}$ & $\begin{array}{c}\% \\
\text { Efficiency }\end{array}$ & $\begin{array}{l}\text { Corr. } \\
\text { Rate }\end{array}$ & $\begin{array}{c}\% \\
\text { Efficiency }\end{array}$ & $\begin{array}{l}\text { Corr. } \\
\text { Rate }\end{array}$ & $\begin{array}{c}\% \\
\text { Efficiency }\end{array}$ & $\begin{array}{l}\text { Corr. } \\
\text { Rate }\end{array}$ & $\begin{array}{c}\% \\
\text { Efficiency }\end{array}$ & $\begin{array}{l}\text { Corr. } \\
\text { Rate }\end{array}$ & $\begin{array}{c}\% \\
\text { Efficiency }\end{array}$ \\
\hline $1 \mathrm{M} \mathrm{HCl}$ & 0.961 & - & 1.394 & - & 4.671 & - & 12.225 & - & 26.280 & - \\
\hline $1 \mathrm{M} \mathrm{HCl}+1 \times 10^{-7} \mathrm{M}$ & 0.950 & 1 & 1.381 & 0.9 & 4.648 & 0.5 & 14.057 & -15 & 28.139 & -7.1 \\
\hline $1 \mathrm{M} \mathrm{HCl}+1 \times 10^{-6} \mathrm{M}$ & 0.916 & 5 & 1.343 & 3.7 & 4.570 & 2.2 & 12.733 & -4 & 27.061 & -3.0 \\
\hline $1 \mathrm{M} \mathrm{HCl}+1 \times 10^{-5} \mathrm{M}$ & 0.714 & 26 & 1.203 & 14 & 4.192 & 10.3 & 12.714 & -4 & 24.901 & 5.2 \\
\hline $1 \mathrm{M} \mathrm{HCl}+1 \times 10^{-4} \mathrm{M}$ & 0.191 & 80 & 0.361 & 74 & 2.179 & 53.4 & 8.959 & 27 & 24.020 & 8.6 \\
\hline $1 \mathrm{M} \mathrm{HCl}+1 \times 10^{-3} \mathrm{M}$ & 0.060 & 94 & 0.112 & 92 & 0.543 & 88.4 & 2.321 & 81 & 8.619 & 67 \\
\hline
\end{tabular}

inhibition of mild steel in $1 \mathrm{M} \mathrm{HCl}$ solution. Mild steel was chosen in our studies since high-temperature aggressive acids are widely used in industries in connection to mild and low alloy steels.

In this work, trans-4-hydroxy-4'-stilbazole was prepared via a synthesis which produced a high percentage yield of this pure compound.

The aim of this work is to study, using weight loss measurements, the effect of temperature on the corrosion inhibition of mild steel in $1 \mathrm{M} \mathrm{HCl}$ solution by trans-

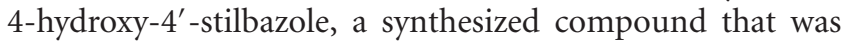
previously studied using electrochemical technique [40] and found to be a very efficient corrosion inhibitor, and to calculate the thermodynamic parameters. Hence, the output of this study is intended to be the building block or the nucleus for a new family or group of stilbazole derivatives in all studies of corrosion inhibitors.

\section{Experimental Details}

2.1. Instrumentation. The experimental setup consisted of a $250 \mathrm{~mL}$ round bottom flask fitted with a reflux condenser and a long glass rod on which the specimen was hooked and in turn immersed in a thermally controlled water bath $[28,42]$.

Analytical-grade hydrochloric acid (Ajax), 4-iodophenol, triethylamine, palladium acetate, tri(o-tolyl)phosphine, acetonitrile, dichloromethane, $\mathrm{MgSO}_{4}$, hexane, and pentane were obtained from Aldrich Chemical Company and used without further purification. 4-Vinylpyridine was distilled under reduced pressure and stored in cold place.

2.2. Sample Preparation. Rectangular specimens $(1 \mathrm{~cm} \times$ $2.3 \mathrm{~cm} \times 0.3 \mathrm{~cm})$ cut from large sheet of $3 \mathrm{~mm}$ thick mild steel (IS 226 containing $0.18 \% \mathrm{C}, 0.6 \% \mathrm{Mn}$, and $0.35 \% \mathrm{Si}$ ) supplied by "Reliable Steel Traders," Sharjah, UAE, were used for weight loss measurements. A $2 \mathrm{~mm}$ diameter hole was drilled close to the upper edge of the specimen and served to be hooked with a glass rod for immersion purposes. Prior to each experiment, the specimens were polished with 600 grade emery paper, rinsed with distilled water, degreased with acetone, dried, and finally weighed precisely on an accurate analytical balance.
2.3. Synthesis of Trans-4-Hydroxy-4'-Stilbazole. Several methods for the synthesis of trans-4-hydroxy- $4^{\prime}$-stilbazole are available including the reaction of 4-picoline with 4-Hydroxy benzaldehyde in acetic anhydride [43, 44], which, under such conditions, gave only tiny yields after long reactions. A better procedure was developed and which used Heck-type vinylic addition reaction [45] catalyzed by palladium. Using this procedure, we were able to obtain a yield of about $80 \%$ and quantities reaching up to $20 \mathrm{~g}$ in one single reaction, following the modified procedure set by [46] and described in our previous work [40].

2.4. Measuring Procedure. The flask was filled with $100 \mathrm{~mL}$ of $1 \mathrm{M} \mathrm{HCl}$ solution either with or without trans-4-hydroxy$4^{\prime}$-stilbazole of various concentrations, then placed in water bath. As soon as the required working temperature was reached, the mild steel sample was immersed in the solution, and left there for exactly six hours, after which the sample was removed, rinsed with distilled deionized water, degreased with acetone, dried, and finally weighed precisely on an accurate analytical balance. This procedure was repeated with all the samples with a variety of inhibitor concentrations ranging from $1 \times 10^{-7} \mathrm{M}$ up to $1 \times 10^{-3} \mathrm{M}$, and at temperatures ranging from $303 \mathrm{~K}$ to $343 \mathrm{~K}$.

\section{Results}

Weight loss corrosion tests were carried out on the mild steel in $1 \mathrm{M} \mathrm{HCl}$ in the absence or presence of trans-4-hydroxy$4^{\prime}$-stilbazole over a period of 6 hours. Table 1 represents the corrosion rates $\left[\mathrm{mg} \cdot \mathrm{cm}^{-2} \cdot \mathrm{h}^{-1}\right]$ and the percentage efficiencies for the studied inhibitor with concentrations varying from $1 \times 10^{-7} \mathrm{M}$ to $1 \times 10^{-3} \mathrm{M}$ at $303,313,323$, 333 , and $343 \mathrm{~K}$, respectively. The percentage efficiency was calculated according to the following expression:

$$
\% \text { Inhibition }=\frac{W_{\text {Uninh. }}-W_{\text {Inh. }}}{W_{\text {Uninh. }}} \times 100,
$$

where $W_{\text {Uninh. }}$ is corrosion rate without inhibitor and $W_{\text {Inh. }}$ is corrosion rate with inhibitor.

Figures 1 and 2 show the plots of the corrosion rate of trans-4-hydroxy- $4^{\prime}$-stilbazole as a function of concentration 


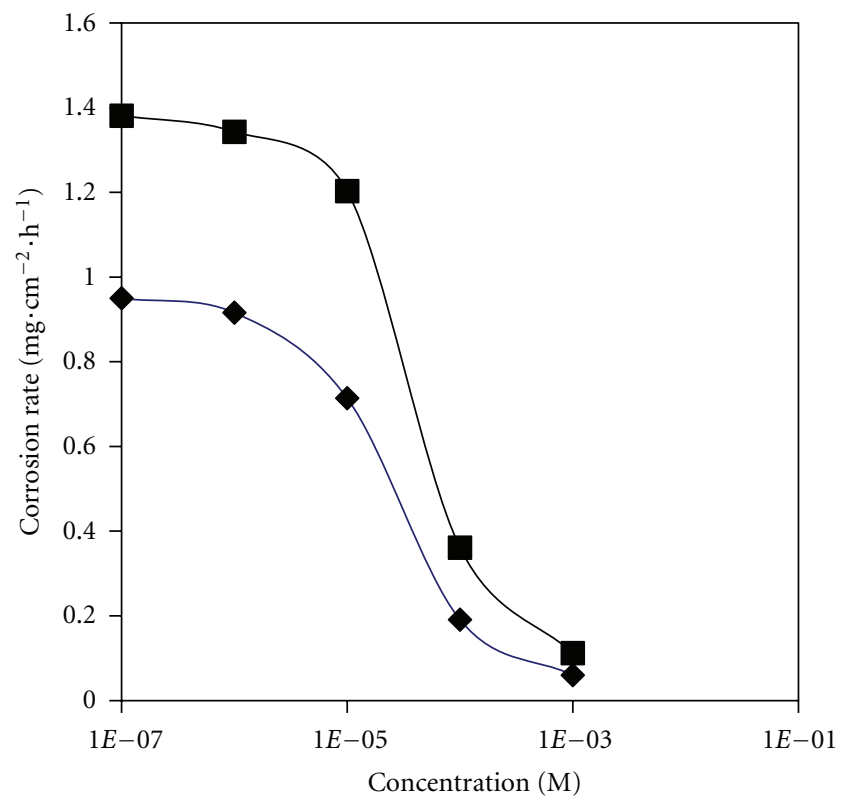

> $303 \mathrm{~K}$

- $313 \mathrm{~K}$

Figure 1: Effect of concentration of trans-4-hydroxy-4'-stilbazole on the corrosion rate $\left(\mathrm{mg} \cdot \mathrm{cm}^{-2} \cdot \mathrm{h}^{-1}\right)$ of mild steel in $1 \mathrm{M} \mathrm{HCl}$ at various temperatures.

at $303,313,323,333$, and $343 \mathrm{~K}$. At $303 \mathrm{~K}$ (Figure 1), the corrosion rate dropped from $0.961 \mathrm{mg} \cdot \mathrm{cm}^{-2} \cdot \mathrm{h}^{-1}(1 \mathrm{M} \mathrm{HCl}$ in the absence of the inhibitor) to $0.950 \mathrm{mg} \cdot \mathrm{cm}^{-2} \cdot \mathrm{h}^{-1}$ when $1 \times 10^{-7} \mathrm{M}$ of trans-4-hydroxy-4 ${ }^{\prime}$-stilbazole was present in the $1 \mathrm{M} \mathrm{HCl}$. This corrosion rate continued to decrease slightly to reach $0.714 \mathrm{mg} \cdot \mathrm{cm}^{-2} \cdot \mathrm{h}^{-1}(26 \%$ inhibition) at a concentration of $1 \times 10^{-5} \mathrm{M}$, followed by a steep decrease to reach $0.191 \mathrm{mg} \cdot \mathrm{cm}^{-2} \cdot \mathrm{h}^{-1}$ when the inhibitor's concentration was $1 \times 10^{-4} \mathrm{M}$, and finally, at higher concentration $\left(1 \times 10^{-3} \mathrm{M}\right)$ the corrosion rate as initially decreased slightly to reach $0.060 \mathrm{mg} \cdot \mathrm{cm}^{-2} \cdot \mathrm{h}^{-1}$ (94\% inhibition). At $313 \mathrm{~K}$ (Figure 1), the curve showed to have similar shape as that obtained at $303 \mathrm{~K}$. At concentrations greater than $1 \times 10^{-5} \mathrm{M}$, the corrosion rate decreased steeply and reached about $0.112 \mathrm{mg} \cdot \mathrm{cm}^{-2} \cdot \mathrm{h}^{-1}(92 \%)$ at $1 \times 10^{-3} \mathrm{M}$.

At $323 \mathrm{~K}$ (Figure 2), when the concentration of the inhibitor was between $1 \times 10^{-7} \mathrm{M}$ and $1 \times 10^{-5} \mathrm{M}$, it had very slight effect on the corrosion rate; whereas at higher concentrations, the corrosion rate dropped from $4.192 \mathrm{mg} \cdot \mathrm{cm}^{-2} \cdot \mathrm{h}^{-1}$ (at $1 \times 10^{-5} \mathrm{M}$ ) down to 2.179 and $0.543 \mathrm{mg} \cdot \mathrm{cm}^{-2} \cdot \mathrm{h}^{-1}$ at $1 \times 10^{-4} \mathrm{M}$ and $1 \times 10^{-3} \mathrm{M}$, respectively.

At $333 \mathrm{~K}$ (Table 1), the presence of trans-4-hydroxy- $4^{\prime}$ stilbazole acted as an accelerator between $1 \times 10^{-7} \mathrm{M}$ and $1 \times 10^{-5} \mathrm{M}$, and at concentrations of $1 \times 10^{-4} \mathrm{M}$ and greater, it acted as inhibitor reaching percentage inhibitions of $27 \%$ and $81 \%$ at $1 \times 10^{-4} \mathrm{M}$ and $1 \times 10^{-3} \mathrm{M}$, respectively. At $343 \mathrm{~K}$, likewise, trans-4-hydroxy-4' $4^{\prime}$-stilbazole acted as an accelerator between $1 \times 10^{-7} \mathrm{M}$ and $1 \times 10^{-6} \mathrm{M}$, then inhibited the mild steel at $1 \times 10^{-5} \mathrm{M}$ and greater concentration, reaching a percentage inhibition of about $67 \%$ at $1 \times 10^{-3} \mathrm{M}$. It was noticed that a tenfold increase in the inhibitor's concentration,

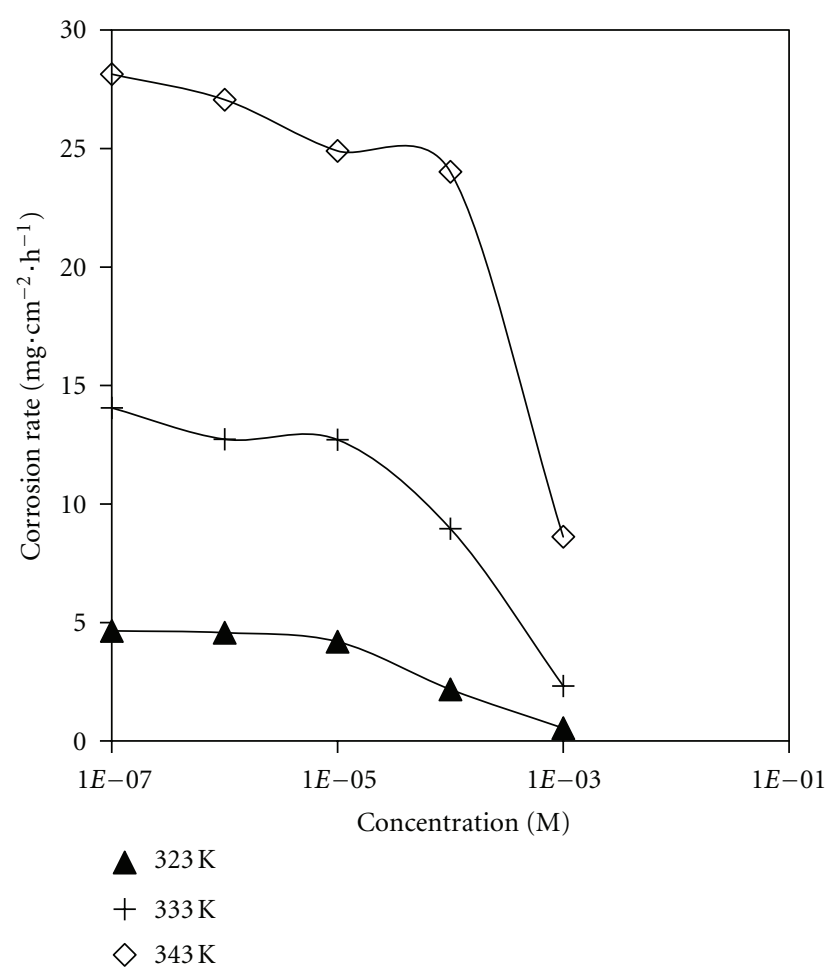

FIGURE 2: Effect of concentration of trans-4-hydroxy- $4^{\prime}$-stilbazole on the corrosion rate $\left(\mathrm{mg} \cdot \mathrm{cm}^{-2} \cdot \mathrm{h}^{-1}\right)$ of mild steel in $1 \mathrm{M} \mathrm{HCl}$ at various temperatures.

namely, from $1 \times 10^{-4} \mathrm{M}$ to $1 \times 10^{-3} \mathrm{M}$, had a very sizeable increase in the percentage inhibition as this increased from $27 \%$ to $81 \%$ at $333 \mathrm{~K}$, and from $8.6 \%$ to $67 \%$ at $343 \mathrm{~K}$.

Figure 3 shows the plots of the percent inhibition versus the concentration of the inhibitor at temperatures of 303, $313,323,333$, and $343 \mathrm{~K}$, respectively. This figure showed that the percent inhibition was not sufficiently affected by the increase of temperature ( 303 to $323 \mathrm{~K}$ ), especially when low concentrations $\left(1 \times 10^{-7}\right.$ to $\left.1 \times 10^{-5} \mathrm{M}\right)$ of inhibitors were employed; whereas at higher concentrations (above $1 \times 10^{-5} \mathrm{M}$ ), the presence of the inhibitor greatly increased the percent inhibition at all temperatures. At higher temperatures, it was noticed that at concentrations between $1 \times 10^{-7} \mathrm{M}$ and $1 \times 10^{-4} \mathrm{M}(343 \mathrm{~K})$ and in some cases to $1 \times 10^{-5} \mathrm{M}(333 \mathrm{~K})$ trans-4-hydroxy-4' ${ }^{\prime}$-stilbazole acted as a corrosion accelerator.

The data obtained from the weight loss measurements were plotted in accordance to Arrhenius equation:

$$
\ln \text { rate }=-\frac{E_{\mathrm{a}}}{R T}+\text { const., }
$$

where $E_{\mathrm{a}}$ is activation energy $\left[\mathrm{kcal} \cdot \mathrm{mol}^{-1}\right.$ ], $R$ is gas constant $\left[\mathrm{kcal} \cdot \mathrm{mol}^{-1}\right], T$ is absolute temperature $[\mathrm{K}]$, and const. is constant.

Figure 4 represents the Arrhenius plot of the corrosion of mild steel in $1 \mathrm{M} \mathrm{HCl}$ solution (ln corrosion rate as a function of $1 / T$ ) with or without the presence of trans-4-hydroxy$4^{\prime}$-stilbazole at concentrations ranging from $1 \times 10^{-7} \mathrm{M}$ to $1 \times 10^{-3} \mathrm{M}$. From this figure, the slope $\left(-E_{\mathrm{a}} / R\right)$ of each 


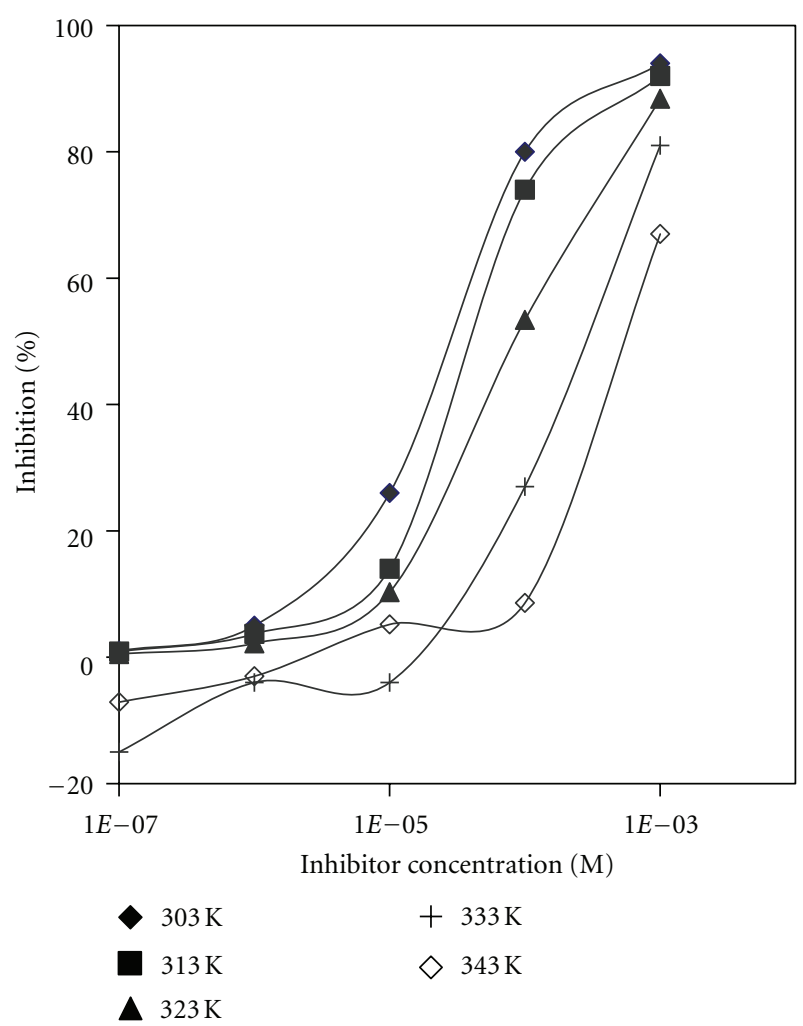

FIGURE 3: Effect of concentration of trans-4-hydroxy-4'-stilbazole on the percent inhibition of mild steel in $1 \mathrm{M} \mathrm{HCl}$ at various temperatures.

individual line was determined and used to calculate the activation energy according to (2), and taking $R=1.987 \times$ $10^{-3} \mathrm{kcal} \cdot \mathrm{mol}^{-1}$ (Table 2). The increase of concentration of trans-4-hydroxy-4' -stilbazole (from $1 \times 10^{-7} \mathrm{M}$ to $1 \times 10^{-3} \mathrm{M}$ ) increased the activation energies for the corrosion of mild steel in $1 \mathrm{M} \mathrm{HCl}$ (initially $18.27 \mathrm{kcal} \cdot \mathrm{mol}^{-1}$ ) (Table 2).

Table 3 shows the surface coverage of various concentrations of trans-4-hydroxy- $4^{\prime}$-stilbazole (from $1 \times 10^{-7} \mathrm{M}$ to $\left.1 \times 10^{-3} \mathrm{M}\right)$ on mild steel surface as a function of temperature. These values were extracted from the corresponding percent efficiency values reported earlier in Table 1 . The plot of surface coverage, $\theta$, against the natural logarithm of the concentration of the inhibitor, $\ln C$, for mild steel at various inhibitor temperatures is shown in Figure 5. After examining these data and adjusting them to different theoretical adsorption isotherms, it was concluded that the inhibitor was adsorbed on the mild steel surface according to Temkin isotherm:

$$
-2 a \theta=\ln K C,
$$

where $a$ is molecular interaction constant, $\theta$ is degree of coverage, $K$ is equilibrium constant for the adsorption reaction, and $C$ is concentration of the inhibitor. The equilibrium constant for the adsorption reaction, $K$, is related to the standard free energy of adsorption [24] via:

$$
K=\frac{1}{55.5} \exp \left(-\frac{\Delta G}{R T}\right)
$$

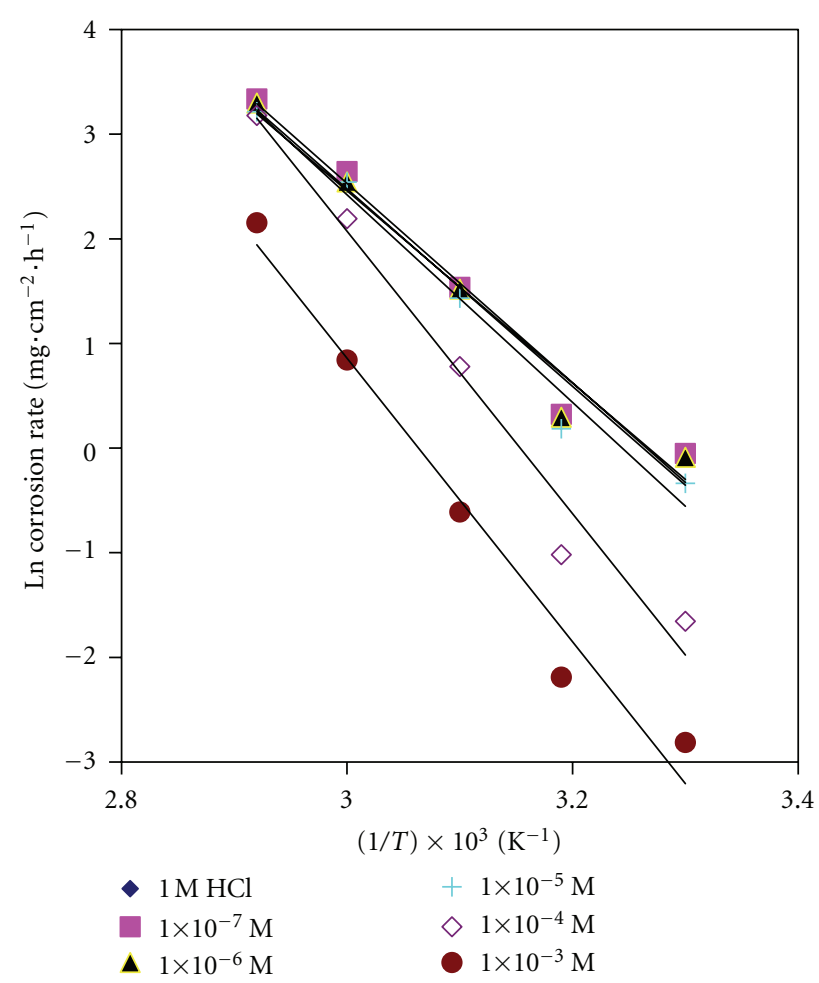

FIGURE 4: Effect of temperature on the corrosion rate of mild steel in $1 \mathrm{M} \mathrm{HCl}$ solution with and without the presence of various concentrations of trans-4-hydroxy- $4^{\prime}$-stilbazole inhibitor.

where $K$ is equilibrium constant for the adsorption reaction, 55.5 is concentration of water $\left[\mathrm{mol} \cdot \mathrm{L}^{-1}\right], \Delta G$ is standard free energy $\left[\mathrm{kcal} \cdot \mathrm{mol}^{-1}\right], R$ is gas constant $\left[\mathrm{kcal} \cdot \mathrm{mol}^{-1}\right]$, and $T$ is absolute temperature $[\mathrm{K}]$.

According to (3), the straight lines shown in Figure 5 will have the following slopes and intercepts:

$$
\begin{aligned}
\text { Slope } & =-\frac{1}{2 a}, \\
\text { Intercept } & =-\frac{1}{2 a} \ln K .
\end{aligned}
$$

Combination of (5) and (6) leads to the following relationship:

$$
\text { Intercept }=\text { Slope } \cdot(\ln K),
$$

from which the equilibrium constant for the adsorption reaction, $K$, can be calculated:

$$
K=e^{(\text {Intercept/Slope })} .
$$

The free energy of adsorption of the inhibitor, $\Delta G$, can be calculated from the results in Figure 5 used to calculate the equilibrium constant, $K$, and (4) at various temperatures ( $303 \mathrm{~K}$ to $323 \mathrm{~K}$ ).

The enthalpy of adsorption, $\Delta H$, for the inhibitor can be calculated from the following equation:

$$
\Delta H=E_{\mathrm{a}}-R T \text {. }
$$


TABLE 2: The activation energy $\left(E_{\mathrm{a}}\right)$ for the corrosion of mild steel in $1 \mathrm{M} \mathrm{HCl}$ with and without trans-4-hydroxy-4' ${ }^{\prime}$-stilbazole inhibitor at various concentrations.

\begin{tabular}{lccccc}
\hline \multirow{2}{*}{ System } & \multicolumn{4}{c}{ Activation energy, $E_{\mathrm{a}}\left(\mathrm{kcal} \cdot \mathrm{mol}^{-1}\right)$} \\
& $1 \times 10^{-3} \mathrm{M}$ & $1 \times 10^{-4} \mathrm{M}$ & $1 \times 10^{-5} \mathrm{M}$ & $1 \times 10^{-6} \mathrm{M}$ & $1 \times 10^{-7} \mathrm{M}$ \\
\hline $1 \mathrm{M} \mathrm{HCl}$ & 18.27 & 18.27 & 18.27 & 18.27 & 18.27 \\
$1 \mathrm{M} \mathrm{HCl}+$ trans-4-hydroxy- & 26.93 & 26.82 & 19.72 & 18.76 \\
$4^{\prime}$-stilbazole & & & 18.93 \\
\hline
\end{tabular}

TABLE 3: Effect of concentration of trans-4-hydroxy-4'-stilbazole on surface coverage for mild steel in $1 \mathrm{M} \mathrm{HCl}$ at various temperatures.

\begin{tabular}{lccc}
\hline & \multicolumn{3}{c}{ Temperature/K } \\
\hline Concentration of & 303 & 313 & 323 \\
inhibitor & $\begin{array}{c}\text { Surface } \\
\text { coverage } \theta\end{array}$ & $\begin{array}{c}\text { Surface } \\
\text { coverage } \theta\end{array}$ & $\begin{array}{c}\text { Surface } \\
\text { coverage } \theta\end{array}$ \\
\hline $1 \mathrm{M} \mathrm{HCl}+1 \times 10^{-6} \mathrm{M}$ & 0.05 & 0.037 & 0.022 \\
$1 \mathrm{M} \mathrm{HCl}+1 \times 10^{-5} \mathrm{M}$ & 0.26 & 0.14 & 0.103 \\
$1 \mathrm{M} \mathrm{HCl}+1 \times 10^{-4} \mathrm{M}$ & 0.80 & 0.74 & 0.534 \\
$1 \mathrm{M} \mathrm{HCl}+1 \times 10^{-3} \mathrm{M}$ & 0.94 & 0.92 & 0.884 \\
\hline
\end{tabular}

The entropy, $\Delta S$, can be calculated at various temperatures for the inhibitor using the following equation:

$$
\Delta G=\Delta H-T \Delta S .
$$

\section{Discussion}

The results in Table 2 show that the activation energy $\left(E_{\mathrm{a}}\right)$ for the corrosion of mild steel in the presence of the inhibitor are higher compared to the activation energy in the absence of inhibitor at both $1 \times 10^{-3} \mathrm{M}$ and $1 \times 10^{-4} \mathrm{M}$ (about 27 versus about $18 \mathrm{kcal} \cdot \mathrm{mol}^{-1}$ ). Whereas at lower concentration (from $1 \times 10^{-5}$ to $1 \times 10^{-7} \mathrm{M}$ ), the activation energy is very close to that in uninhibited $\mathrm{HCl}$ solution. This can be attributed to the fact that higher values of $E_{\mathrm{a}}$ in the presence of inhibitor compared to its absence are generally consistent with a physisorption, while unchanged or lower values of $E_{\mathrm{a}}$ in inhibited solution suggest charge sharing or transfer from the organic inhibitor to the metal surface to form coordinate covalent bonds (chemisorption).

The increase in the activation energies for the corrosion is attributed to a decrease in the adsorption of the inhibitor on the metal surface as the temperature increased; subsequently, an increase in the corrosion rate will result due to the greater exposed area of the metal surface to the acid.

Tables 4, 5, and 6 show the thermodynamic data obtained in the presence of the inhibitor at various temperatures. These thermodynamic quantities represent the algebraic sum of the values for adsorption and desorption. The negative value of $\Delta G$ indicates the spontaneous adsorption of inhibitor on the surface of the mild steel. The free energy, $\Delta G$, varies from $-11.54 \mathrm{kcal} \cdot \mathrm{mol}^{-1}$ at $303 \mathrm{~K}$ to $-11.12 \mathrm{kcal} \cdot \mathrm{mol}^{-1}$ at $323 \mathrm{~K}$. The adsorption process is believed to be exothermic and associated with a decrease in entropy $(\Delta S)$ of solute, while the opposite is true for the solvent [31]. The gain in entropy which accompanies the

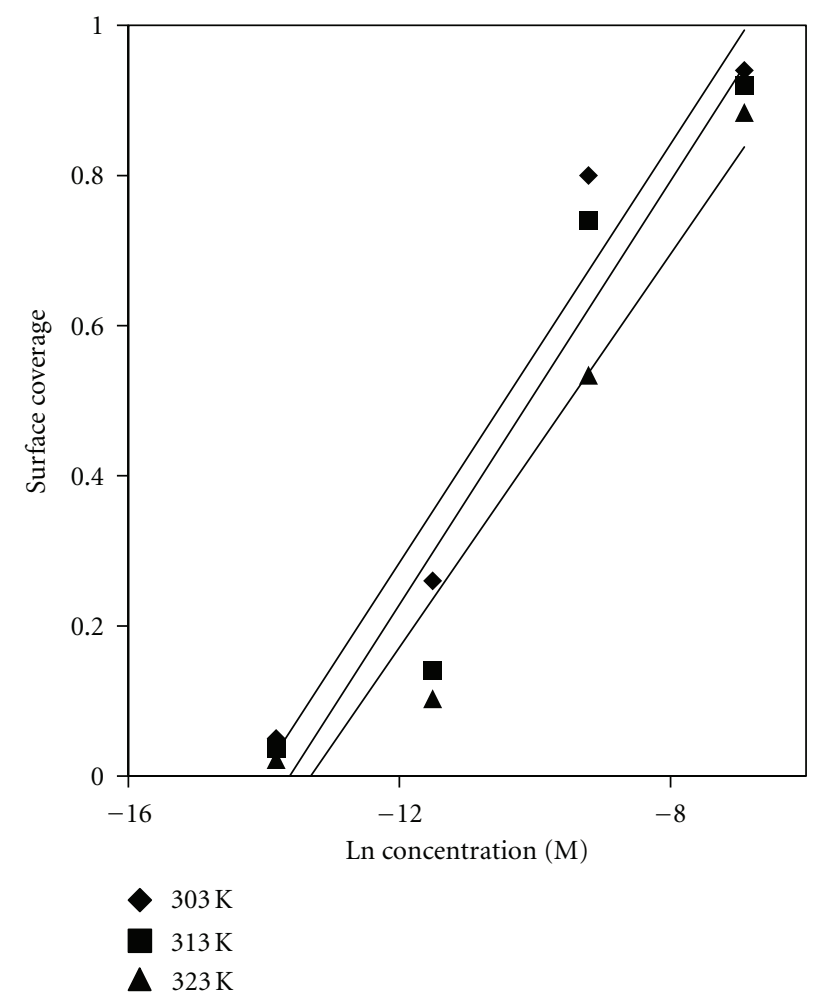

Figure 5: Effect of concentration of trans-4-hydroxy-4'-stilbazole on the surface coverage of mild steel in $1 \mathrm{M} \mathrm{HCl}$ at various temperatures.

TABLE 4: The enthalpy of adsorption $(\Delta H)$ for mild steel in $1 \mathrm{M} \mathrm{HCl}$ in the presence of $1 \times 10^{-3} \mathrm{M}$ trans-4-hydroxy-4' -stilbazole inhibitor at various temperatures ( $303 \mathrm{~K}-343 \mathrm{~K})$.

\begin{tabular}{lcccc}
\hline \multicolumn{5}{c}{$\Delta H, \mathrm{kcal} \cdot \mathrm{mol}^{-1}$} \\
\hline $303 \mathrm{~K}$ & $313 \mathrm{~K}$ & $323 \mathrm{~K}$ & $333 \mathrm{~K}$ & $343 \mathrm{~K}$ \\
26.33 & 26.31 & 26.29 & 26.27 & 26.25 \\
\hline
\end{tabular}

substitutional adsorption process is attributed to the increase in the solvent entropy (Table 6). This agrees with the general suggestion that the values of $\Delta G$ increase with the increase of inhibition efficiency $[20,26]$ as the adsorption of organic compound is accompanied by desorption of water molecules off the surface.

The electron density group $(-\mathrm{OH})$ on the phenyl ring gives an extra inhibition effect. The high inhibition efficiency may be attributed to the preferred flat orientation of this compound on the metal surface. The interaction occurs 
TABLE 5: The free energy of adsorption $\left(\Delta G_{\text {ads }}\right)$ for mild steel in $1 \mathrm{M} \mathrm{HCl}$ in the presence of trans-4-hydroxy- $4^{\prime}$-stilbazole inhibitor at various temperatures $(303 \mathrm{~K}-323 \mathrm{~K})$.

\begin{tabular}{lcc}
\hline \multicolumn{3}{c}{$\Delta G, \mathrm{kcal} \cdot \mathrm{mol}^{-1}$} \\
\hline $303 \mathrm{~K}$ & $313 \mathrm{~K}$ & $323 \mathrm{~K}$ \\
-11.54 & -11.76 & -11.12 \\
\hline
\end{tabular}

TABle 6: The change in entropy $(\Delta S)$ for mild steel in $1 \mathrm{M} \mathrm{HCl}$ in the presence of trans-4-hydroxy-4'-stilbazole inhibitor at various temperatures $(303 \mathrm{~K}-323 \mathrm{~K})$.

\begin{tabular}{lcc}
\hline \multicolumn{3}{c}{$\Delta S, \mathrm{kcal} \cdot \mathrm{K}^{-1} \cdot \mathrm{mol}^{-1}$} \\
\hline $303 \mathrm{~K}$ & $313 \mathrm{~K}$ & $323 \mathrm{~K}$ \\
0.125 & 0.122 & 0.116 \\
\hline
\end{tabular}

between the delocalized $\pi$-electrons of the two rings, the double bond $(-\mathrm{C}=\mathrm{C}-)$, and the lone pair of electrons on $\mathrm{N}$ and $\mathrm{O}$ atoms with the positively charged metal surface. In addition, $(-\mathrm{C}=\mathrm{C}-)$ bond plays the major role in the stabilization of both sides of the Stilbazole structure.

These results agree with [27] who suggested that the inhibition efficiency of organic compounds depends on many factors including their charge density, number of adsorption sites, heat of hydrogenation, mode of interaction with the metal surface, and formation of metallic complexes [37].

\section{Conclusion}

Trans-4-hydroxy-4' -stilbazole was found to be a highly efficient inhibitor for mild steel in $1.0 \mathrm{M} \mathrm{HCl}$ solution, reaching about $94 \%$ at $1.0 \times 10^{-3} \mathrm{M}$ and $303 \mathrm{~K}$, a concentration considered to be very moderate.

Trans-4-hydroxy-4'-stilbazole is a potential corrosion inhibitor since it contains not only nitrogen and oxygen, but also phenyl and pyridine rings that are joined together with a double bond $(-\mathrm{C}=\mathrm{C}-)$ in conjugation with these rings. It was apparent from the molecular structure that this compound would be adsorbed onto the metal surface through the lone pair of electron of nitrogen and oxygen and pi electrons of the two aromatic rings (phenyl and pyridine) and the double bond that join them together.

The percentage of inhibition in the presence of this inhibitor was decreased with temperature, which indicates that physical adsorption was the predominant inhibition mechanism because the quantity of adsorbed inhibitor decreases with increasing temperature.

\section{References}

[1] B. B. Damaskin, O. A. Pietrij, and W. W. Batrokov, "Adsorpcja organiczeskich sojedinienij na electrodach,” Moskva, 1968.

[2] G. Okamoto, M. Nagayama, J. Kato, and T. Baba, "Effect of organic inhibitors on the polarization characteristics of mild steel in acid solution," Corrosion Science, vol. 2, no. 1, pp. 2127, 1962.
[3] S. M. Beloglazov, Z. I. Dzhafarov, V. N. Polyakov, and N. N. Demushia, "Quaternary ammonium salts as corrosion inhibitors of steel in the presence of sulfate-reducing bacteria," Protection of Metals USSR, vol. 27, no. 6, pp. 810-813, 1991.

[4] A. V. Fokin, M. V. Pospelov, and A. N. Levichev, "Structural and protective capacities of organic corrosion inhibitors. 2. Alkylethylene diamines and quaternary ammonium salts," Protection of Metals USSR, vol. 19, no. 2, pp. 242-244, 1983.

[5] A. H. Nahlé, "Electrochemical studies of corrosion inhibition of a series of quaternary ammonium salts on iron in $\mathrm{HCl}$ solution," Corrosion Prevention and Control, vol. 44, no. 4, pp. 99-105, 1997.

[6] A. H. Nahlé, "Inhibition of iron in $\mathrm{HCl}$ using benzyl trimethyland triethyl-ammonium chlorides," Corrosion Prevention and Control, vol. 45, no. 4, pp. 124-130, 1998.

[7] A. Nahlé, "Effect of triethanolamine on the electrochemical dissolution of solder in $\mathrm{NaOH}$ solution," Bulletin of Electrochemistry, vol. 18, no. 3, pp. 105-110, 2002.

[8] A. Nahle and F. C. Walsh, "Electrochemical studies of two corrosion inhibitors for iron in $\mathrm{HCl}$ : cetyltrimethyl ammonium bromide and tetraphenyl phosphonium chloride," Corrosion Prevention and Control, vol. 42, no. 2, pp. 30-34, 1995.

[9] B. V. Savithri and S. M. Mayanna, "Tetrabutyl ammonium iodide, cetyl pyridinium bromide and cetyl trimethyl ammonium bromide as corrosion inhibitors for mild steel in sulphuric acid," Indian Journal of Chemical Technology, vol. 3, no. 5, pp. 256-258, 1996.

[10] T. Vasudevan, S. Muralidharan, S. Alwarappan, and S. V. K. Iyer, "The influence of N-hexadecyl benzyl dimethyl ammonium chloride on the corrosion of mild steel in acids," Corrosion Science, vol. 37, no. 8, pp. 1235-1244, 1995.

[11] S. Muralidharan, K. L. N. Phani, S. Pitchumani, S. Ravichandran, and S. V. K. Iyer, "Polyamino-benzoquinone polymers: a new class of corrosion inhibitors for mild steel," Journal of the Electrochemical Society, vol. 142, no. 5, pp. 1478-1483, 1995.

[12] O. Benali, L. Larabi, M. Traisnel, L. Gengembre, and Y. Harek, "Electrochemical, theoretical and XPS studies of 2-mercapto1-methylimidazole adsorption on carbon steel in $1 \mathrm{M} \mathrm{HClO}_{4}$," Applied Surface Science, vol. 253, no. 14, pp. 6130-6139, 2007.

[13] E. S. H. E. Ashry, A. E. Nemr, S. A. Essawy, and S. Ragab, "Corrosion inhibitors part V: QSAR of benzimidazole and 2substituted derivatives as corrosion inhibitors by using the quantum chemical parameters," Progress in Organic Coatings, vol. 61, no. 1, pp. 11-20, 2008.

[14] K. F. Khaled, "The inhibition of benzimidazole derivatives on corrosion of iron in $1 \mathrm{M} \mathrm{HCl}$ solutions," Electrochimica Acta, vol. 48, no. 17, pp. 2493-2503, 2003.

[15] A. Popova, "Temperature effect on mild steel corrosion in acid media in presence of azoles," Corrosion Science, vol. 49, no. 5, pp. 2144-2158, 2007.

[16] A. Popova, M. Christov, S. Raicheva, and E. Sokolova, "Adsorption and inhibitive properties of benzimidazole derivatives in acid mild steel corrosion," Corrosion Science, vol. 46, no. 6, pp. 1333-1350, 2004.

[17] A. Popova, M. Christov, and A. Zwetanova, "Effect of the molecular structure on the inhibitor properties of azoles on mild steel corrosion in $1 \mathrm{M}$ hydrochloric acid," Corrosion Science, vol. 49, no. 5, pp. 2131-2143, 2007.

[18] V. S. Sastri, J. R. Perumareddi, M. Lashgari, and M. Elboujdaini, "Application of ligand field theory in corrosion inhibition," Corrosion, vol. 64, no. 4, pp. 283-288, 2008.

[19] K. Tebbji, A. Aouniti, A. Attayibat et al., "Inhibition efficiency of two bipyrazole derivatives on steel corrosion in 
hydrochloric acid media," Indian Journal of Chemical Technology, vol. 18, pp. 244-253, 2011.

[20] J. D. Talati, M. N. Desai, and N. K. Shah, "Meta-substituted aniline-N-salicylidenes as corrosion inhibitors of zinc in sulphuric acid," Materials Chemistry and Physics, vol. 93, no. 1, pp. 54-64, 2005.

[21] T. Tüken, B. Yazici, and M. Erbil, "The effect of nicotinamide on iron corrosion in chloride solutions," Turkish Journal of Chemistry, vol. 26, no. 5, pp. 735-742, 2002.

[22] A. A. A. Fattah, E. M. Mabrouk, R. M. A. Elgalil, and M. M. Ghoneim, "N-heterocyclic compounds as corrosion inhibitors for $\mathrm{Zn}$ in $\mathrm{HCl}$ acid solutions," Bulletin de la Societé Chimique de France, vol. 1, pp. 48-53, 1991.

[23] S. L. Granese, B. M. Rosales, C. Oviedo, and J. O. Zerbino, "The inhibition action of heterocyclic nitrogen organic compounds on Fe and steel in $\mathrm{HCl}$ media," Corrosion Science, vol. 33, no. 9, pp. 1439-1453, 1992.

[24] H. A. Al-Lohedan, E. Khamis, and Z. A. Issa, "Studies on the influence of temperature on the adsorption of some cationic surfactants on to steel," Adsorption Science and Technology, vol. 13, no. 3, pp. 137-152, 1996.

[25] L. G. Qiu, A. J. Xie, and Y. H. Shen, "A novel triazole-based cationic gemini surfactant: synthesis and effect on corrosion inhibition of carbon steel in hydrochloric acid," Materials Chemistry and Physics, vol. 91, no. 2-3, pp. 269-273, 2005.

[26] B. G. Ateya, B. E. El-Anadouli, and F. M. El-Nizamy, "The effect of thiourea on the corrosion kinetics of mild steel in $\mathrm{H}_{2} \mathrm{SO}_{4}$," Corrosion Science, vol. 24, no. 6, pp. 497-507, 1984.

[27] A. S. Fouda, M. N. Mousa, F. I. Taha, and A. I. Elneamaa, "The role of some thiosemicarbazide derivatives in the corrosion inhibition of aluminum in $\mathrm{HCl}$," Corrosion Science, vol. 26, no. 9, pp. 719-726, 1986.

[28] A. Nahlé, "Effect of temperature on the corrosion inhibition of carbon steel in $\mathrm{HCl}$ solutions," Bulletin of Electrochemistry, vol. 17, no. 5, pp. 221-226, 2001.

[29] A. Nahlé, "Inhibition of corrosion of iron in $\mathrm{HCl}$ solution by semicarbazides and thiosemicarbazides," Bulletin of Electrochemistry, vol. 21, no. 6, pp. 275-281, 2005.

[30] S. N. Raicheva, B. V. Aleksiev, and E. I. Sokolova, "The effect of the chemical structure of some nitrogen- and sulphurcontaining organic compounds on their corrosion inhibiting action," Corrosion Science, vol. 34, no. 2, pp. 343-350, 1993.

[31] S. H. Sanad, A. A. Ismail, and A. A. El-Meligi, "The effect of temperature on the corrosion and corrosion inhibition of steel alloys in hydrochloric acid solutions," Bulletin of Electrochemistry, vol. 11, no. 10, pp. 462-469, 1995.

[32] F. Zucchi, G. Trabanelli, and G. Brunoro, "The influence of the chromium content on the inhibitive efficiency of some organic compounds," Corrosion Science, vol. 33, no. 7, pp. 1135-1139, 1992.

[33] Y. L. Huang, C. N. Cao, M. Lu, and H. C. Lin, "Inhibition effects of $\mathrm{I}^{-}$and $\mathrm{I}_{2}$ on stress corrosion cracking of stainless steel in acidic chloride solutions," Corrosion, vol. 49, no. 8, pp. 644-649, 1993.

[34] A. Popova, M. Christov, and T. Deligeorgiev, "Influence of the molecular structure on the inhibitor properties of benzimidazole derivatives on mild steel corrosion in $1 \mathrm{M}$ hydrochloric acid," Corrosion, vol. 59, no. 9, pp. 756-764, 2003.

[35] M. Scendo and M. Hepel, "Inhibiting properties of benzimidazole films for $\mathrm{Cu}(\mathrm{II}) / \mathrm{Cu}(\mathrm{I})$ reduction in chloride media studied by RDE and EQCN techniques," Journal of Electroanalytical Chemistry, vol. 613, no. 1, pp. 35-50, 2008.
[36] M. Yamaguchi, H. Nishihara, K. Aramaki, M. Tomihari, and S. Furuya, "The inhibitive effect of organic cations on passive film breakdown of iron in a chloride-containing borate buffer solution," Corrosion Science, vol. 36, no. 7, pp. 1133-1141, 1994.

[37] A. S. Fouda, A. Abd El-Aal, and A. B. Kandil, "The effect of some phthalimide derivatives on the corrosion behaviour of copper in nitric acid," Anti-Corrosion Methods and Materials, vol. 52, no. 2, pp. 96-101, 2005.

[38] K. Kobayashi, K. Shimizu, and M. Iida, "Structural effects of organic compounds as corrosion inhibitors for hydrogen entry into iron in sulphuric acid," Corrosion Science, vol. 35, no. 5-8, pp. 1431-1435, 1993.

[39] L. D. Skryler, E. A. Streltsova, and T. L. Skryleva, "Hydrocarbon chain length and their effect on corrosion inhibition by alkylammonium chlorides," Protection of Metals USSR, vol. 27, no. 6, pp. 755-758, 1991.

[40] A. Nahlé, I. Abu-Abdoun, and I. Abdel-Rahman, "Electrochemical studies of the effect of trans-4-hydroxy-4'-stilbazole on the corrosion inhibition of mild steel in $\mathrm{HCl}$ solution," Anti-Corrosion Methods and Materials, vol. 54, no. 4, pp. 244248, 2007.

[41] A. Nahlé, I. Abu-Abdoun, and I. Abdel-Rahman, "Inhibition of carbon steel corrosion by 4-vinylbenzyl triphenyl phosphonium chloride in $\mathrm{HCl}$ solution," Anti-Corrosion Methods and Materials, vol. 55, no. 4, pp. 217-224, 2008.

[42] A. Nahlé, I. Abdel-Rahman, and M. Alfarouk, "Effect of temperature on the inhibition of corrosion of carbon steels by semicarbazides and thiosemicarbazides," Bulletin of Electrochemistry, vol. 21, no. 8, pp. 353-361, 2005.

[43] U. Kumar, T. Kato, and J. M. J. Fréchet, "Use of intermolecular hydrogen bonding for the induction of liquid crystallinity in the side chain of polysiloxanes," Journal of the American Chemical Society, vol. 114, no. 17, pp. 6630-6639, 1992.

[44] B. D. Shaw and E. A. Wagstaff, "26. The reaction between 2-picoline and aromatic aldehydes," Journal of the Chemical Society (Resumed), pp. 77-79, 1933.

[45] W. C. Frank, Y. C. Kim, and R. F. Heck, "Palladium-catalyzed vinylic substitution reactions with heterocyclic bromides," Journal of Organic Chemistry, vol. 43, no. 15, pp. 2947-2949, 1978.

[46] D. W. Bruce, S. C. Davis, D. A. Dunmur, S. A. Hudson, P. M. Maitlis, and P. Styring, "Mesomorphic metal complexes derived from 4-alkyloxystilbazoles," Molecular Crystals and Liquid Crystals Science and Technology Section A, vol. 215, no. 2, pp. 1-11, 1992. 

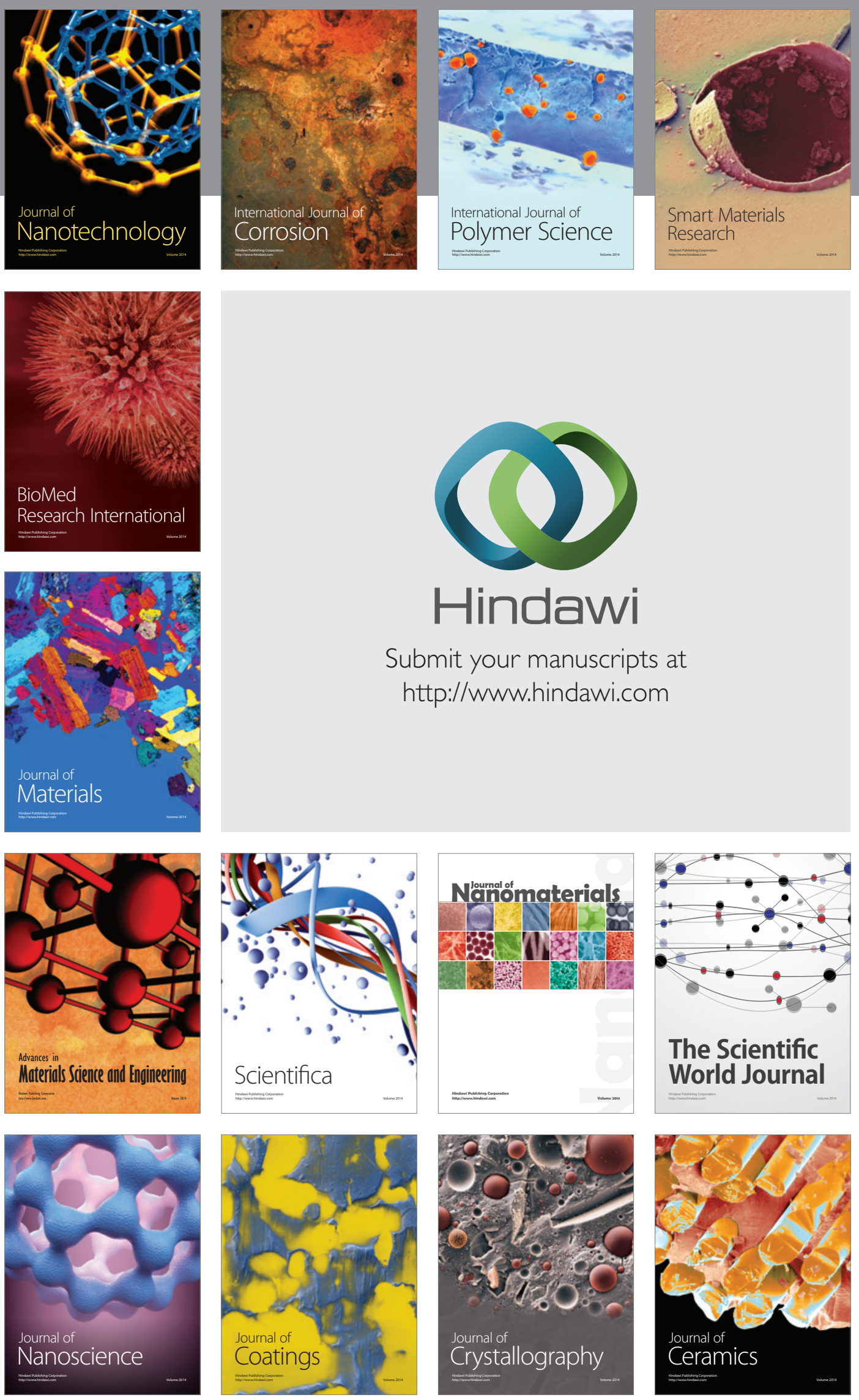

The Scientific World Journal

Submit your manuscripts at

http://www.hindawi.com

\section{World Journal}

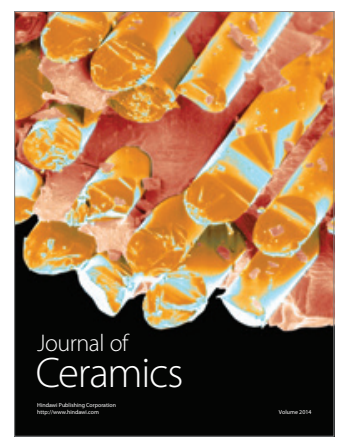

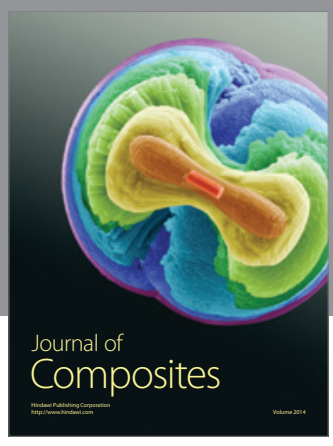
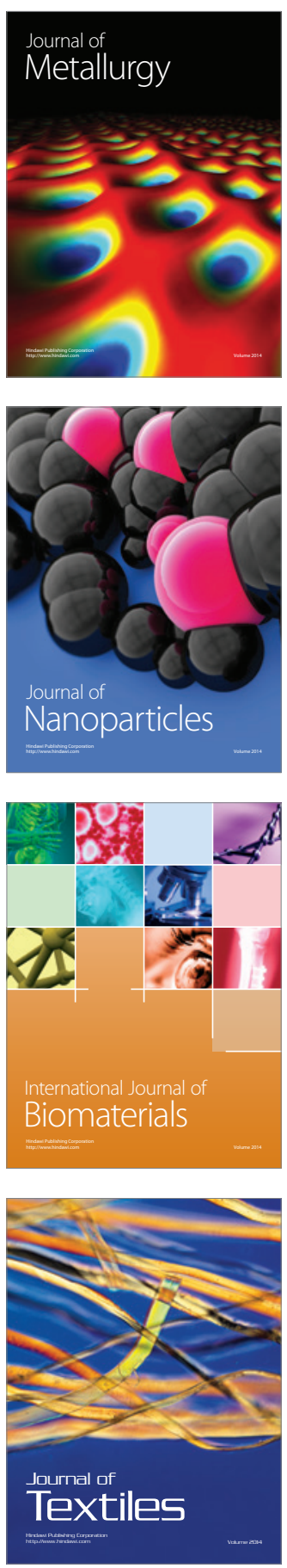